Received: 2016.07.11 Accepted: 2016.08.31 Published: 2016.11.22

Authors' Contribution: Study Design A Data Collection B Statistical Analysis C Data Interpretation D Manuscript Preparation E Literature Search F Funds Collection G

\section{Recent Progress in Xenotransplantation, with Emphasis on Virological Safety}

Department of HIV and Other Retroviruses, Robert Koch Institute, Berlin, Germany
Corresponding Author: Source of support:
MeSH Keywords:

Full-text PDF:
Xenotransplantation is a new technology that may help to overcome the shortage of human tissues and organs available for the treatment of tissue and organ failure. Remarkable progress has recently been made in this field. First, understanding of the mechanisms of immunological rejection, mainly of the hyperacute rejection, allowed generating numerous genetically modified pigs to overcome rejection. Second, based on these genetically modified animals and new immunosuppression regimens, long-term survival of non-human primate recipients of heart, kidney, and islet cell cells has been reported. And third, potential zoonotic microorganisms have been identified in pigs and sensitive methods to detect them have been generated. In 2 clinical trials treating diabetic patients with porcine islet cells, no porcine microorganisms were transmitted to human recipients. Furthermore, strategies to eliminate potentially zoonotic microorganisms from donor pigs in order to prevent transmission to the recipients have been developed, including designated pathogen-free (DPF) breeding. In addition, strategies to prevent transmission of porcine endogenous retroviruses (PERVs) have been developed, including a knockout of all proviruses in the pig genome by gene editing. PERVs are integrated in the genome of all pigs and therefore they cannot be eliminated by DPF breeding. Since they are able to infect human cells, they represent a special risk in xenotransplantation. Despite the achievements, some problems remain: numerous genetically multi-modified pigs have been generated without fully evaluating their advantage, and microbiological screening of pigs to be used for transplantations and elimination of pathogenic microorganisms from the donor pigs are still not satisfactory.

\section{Microbiological Safety • Transplant Rejection • Transplant Survival • Xenotransplantation}

http://www.annalsoftransplantation.com/abstract/index/idArt/900531

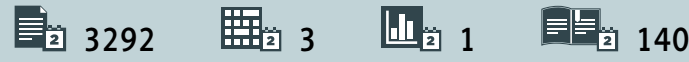




\section{Background}

The shortage of human organs for the treatment of tissue and organ failure is well known. There are several ways to cope with this: prevention of diseases leading to organ failure, increase of the number of human donors, and implantable electromechanical devices, which have been explored in the field of cardiac transplantation. However, these strategies will not be a solution for most of the patients on the waiting list. An alternative would be to create vascularized organs from stem cells, which is currently far from reality. Another solution could be xenotransplantation, which is transplantation of cells, tissues, or organs from another species. Pigs are for many reasons (e.g., size, physiology, large number of progeny, and genetic modification) the favored donor species. Xenotransplantation using pig cells, tissues and organs has to overcome 3 hurdles before being applied in the clinic (Figure 1): immunological rejection, physiological incompatibility, and risk of transmission of potentially pathogenic microorganisms, which may induce a zoonosis. Microbiological safety is very important and porcine endogenous retroviruses (PERVs) are of special interest because they are integrated in the genome of all pigs and cannot be eliminated (like many other potentially zoonotic pig microorganisms) by specified or designated pathogen-free (SPF or DPF) breeding. Here we summarize the recent successes in the field.

\section{Immunological Rejection}

In comparison to allotransplantation, the immunological rejection of pig tissues and organs is much more complex. The first step of immunological rejection in xenotransplantation is hyperacute rejection (HAR), which is well studied. HAR is based on pre-existing antibodies directed mainly against galactose$\alpha$ 1,3-galactose [Gal $\alpha 13$ Gal $\beta 1$ - [3]4GIcNAc-R, $\alpha$-gal] epitopes. The $\alpha$-gal epitope is abundantly synthesized on glycolipids and glycoproteins of non-primates and New World monkeys by the glycosylation enzyme $\alpha 1$,3galactosyltransferase ( $\alpha 1,3 \mathrm{GT}$ ) [1]. In humans, apes, and Old World monkeys, this epitope is absent because the $\alpha 1,3 \mathrm{GT}$ gene was inactivated in ancestral Old World primates. Instead, humans, apes, and Old World monkeys produce anti-Gal antibodies, which specifically interact with $\alpha$-gal epitopes and which constitute $\sim 1 \%$ of circulating immunoglobulins [1]. Since $\alpha$-gal epitopes are present on the surface of bacterial cells and cells from other animals, the antibodies directed against the $\alpha$-gal epitope represent a powerful tool to protect against bacterial infection, as well as from the transmission of foreign cells. When anti-Gal antibodies interact with pig cells, they activate complement and induce the rejection of the pig transplant [2]. Based on this knowledge, transgenic animals were created, overcoming the rejection process. There are 2 ways to prevent rejection: by a knockout of the cellular enzyme $\alpha 1,3 \mathrm{GT}$ (GTKO pigs), which is adding $\alpha$-gal

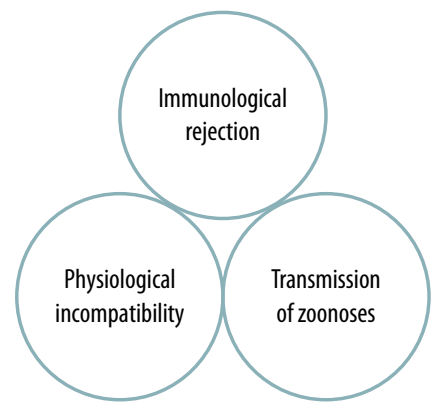

Figure 1. Xenotransplantation: Main hurdles.

epitopes to pig cell surface molecules [3], and by expression of human complement-regulatory proteins such as hCD46, hCD55, and hCD59 on pig cells (for review, see [4]). Animals expressing different combinations of the complement-regulatory proteins have been created (for overview, see Table 2 in [5]). In addition, immune $T$ cell responses were reduced by simultaneous expression of CTLA4-IgG and mutant MHC class II transactivator [6-9].

$\alpha$-gal epitopes and $2 \mathrm{~N}$-glycoylneuraminic acid-terminated (Neu5Gc) gangliosides are targets for pre-existing antibodies in human sera [10]. The expression of Neu5Gc is also specific for pigs and some other animals, but not for humans, because the corresponding enzyme, cytidine monophosphate- $\mathrm{N}$-acetylneuramic acid hydrolase (CMAH), was inactivated during primate evolution [11]. Double-knockout pigs deficient in $\alpha$-gal and Neu5Gc significantly reduce the humoral barrier to xenotransplantation [11]. Using zinc finger nuclease (ZFN) technology, GGTA1/CMAH knockout pigs were produced [11], which were characterized by a reduced binding of human antibodies to transgenic peripheral blood mononuclear cells (PBMCs) in vitro [12]. In lung perfusion experiments, hCD46 expression in GTKO pigs down-regulated complement activation, diminished platelet and coagulation cascade activation, neutrophil sequestration, and histamine release [13]. Altogether, transplants from these genetically modified pigs are characterized by significantly reduced rejection.

When HAR is averted, xenotransplants become subject to acute vascular rejection (named because of its similarity to acute vascular rejection in allotransplantation), also called acute humoral xenotransplant rejection (AHXR) or delayed xenotransplant rejection. Expression of human proteins involved in endothelial activation, such as heme oxygenase 1 (HO-1) [14] or tumor necrosis factor-induced human protein A20 [15], as well as of human antithrombotic or anticoagulant genes such as tissue factor pathway inhibitor (TFPI), endothelial protein $C$ receptor (EPCR), or thrombomodulin (TM), may also enhance xenotransplant survival [16]. In the case of islet preparations, cellular reactions usually play the dominant role in islet xenotransplant 
rejection. Blocking $T$ cell activation by antigen-presenting cells (APC) via interfering with the co-stimulatory systems CD40CD40L and/or CD80/86-CD28 could be utilized to reduce this reaction [17-21]. In a pig-to-humanized mouse transplantation, transgenic porcine islet cell clusters expressing the $T$ cell costimulation blocking molecule LEA29Y normalized blood glucose levels of diabetic mice and were, in contrast to wildtype porcine islets, protected against rejection by human immune cells [22]. T cell activation is regulated by co-stimulatory as well as by co-inhibitory receptor-ligand interactions. Enhancing inhibitory signals by transgenic expression of respective ligands on porcine cells is an attractive new concept to diminish human anti-pig cellular immune responses [23]. The observation that immune responses to pig cells overexpressing the human inhibitory ligand PD-L1 (CD274) are particularly weak in vitro and in vivo supports the relevance of this approach $[24,25]$. It was proposed that combining blockade of co-stimulatory signalling pathways (e.g., by CTLA-4.Ig/LEA29Y) with an enhancement of inhibitory signals by targeting the PD-1/PD-L1 pathway should be highly effective in controlling cell-mediated rejection of xenotransplants [26]. Regulatory $T$ cells (Tregs) represent another approach to inhibit T cell-mediated rejection $[27,28]$. In addition, natural killer (NK) cells, macrophages, and neutrophils are critical components of the cellular response in xenotransplant rejection [29-31]. For example, expression of HLA-E, an inhibitor of NK cell activation, has been found to protect porcine cells from destruction by primate NK cells [32]. T cell responses against the xenotransplant are closely associated with immediate blood-mediated inflammatory reaction (IBMIR) $[33,34]$ and the resulting activation of complement factors and coagulation [34].

Numerous genetically-altered pigs have been generated, but their real advantage for the survival of pig cells, tissues, and organs has not been evaluated.

\section{Increased Survival Times}

Due to the newly generated genetically modified pigs and new and effective immunosuppressive treatments preventing antibody and immune $T$ cell responses, a prolonged survival of the transplants was observed. A comprehensive overview of the experimental transplantations in the years until 2013 is given by Cooper et al. [35]. To demonstrate the development in the field, the longest survival times listed by Cooper et al. [35] and survival times published later [6,36-43] are summarized in Tables 1 and 2. The ability to modify pigs genetically to protect the donor organs from the primate's immune response has resulted in survival of heterotopic pig hearts in baboons for longer than 2.5 years [39-41,44,45] (Table 1). Increase in immunosuppression, but not in anticoagulation, improved heterotopic GTKO pig heart survival in baboons [46].
In contrast to the heterotopic heart xenotransplantations, the survival time of orthotopic xenotransplantations is much shorter (at present, up to 57 days; Table 1). In this context it seems useful to remember the initial survival times in the first clinical heart allotransplantations; the first recipient lived for 18 days and the second for 19 months (for a historical overview, see [47]).

Life-supporting pig kidneys survived for almost 3 months in NHP $[48,49]$ (Table 1). Expression of human complement pathway-regulatory proteins, hCD46 or hCD55, in combination with GTKO reduced the incidence of early transplant failure (loss of function within 3 days of transplantation) to $7 \%$, but did not prevent systemic coagulation activation [50]. Encouraging results were obtained when a GTKO pig transgenic for CD46, CD55, thrombomodulin (TBM), endothelial proteins $C$ receptor (CD39), and blood type 0 donor was used. Although the expression of CD39 and TBM was low, a kidney from this animal transplanted under an effective immunosuppressive therapy and using anti-inflammatory agents was functional for 136 days [8, 42] (Table 1). A survival time of over 125 days was observed when kidneys from CTKO/CD55 pigs were transplanted and the recipients were treated with anti-CD154 monoclonal antibodies [41]. Experience with pig liver xenotransplantation, however is sparse, with maximum graft survival in the NHP of only 9 days [51-53].

\section{Physiological Compatibility}

At present, the physiological compatibility is difficult to evaluate since the survival time of the transplanted organs is usually too short to analyze the long-term functionality of the transplant and its interaction with the transplant recipient in detail. When the physiological aspects of pig to non-human primate renal xenotransplantation were studied using organs from pigs transgenic for human decay accelerating factor (hDAF, hCD55), the porcine kidneys largely maintained plasma electrolyte homeostasis, but an increase in proteinuria and severe anemia were detected in the recipient [54]. The anemia, often observed in renal pig to non-human primate xenotransplantation, could be related to the inability of porcine erythropoietin to adequately stimulate primate hematopoietic precursors, and treatment of the recipient with exogenous human erythropoietin will be required. Alternatively, the generation of transgenic pigs producing sufficient amounts of human erythropoietin may solve the problem.

More difficult is the situation with pig liver transplantation [55]. In pig to non-human primate studies, the transplantation of livers from pigs transgenic for hCD55 or from GTKO animals, which in addition expressed hCD46, was associated with a survival time of 7 to 9 days [55-57]. Although hepatic functions, 
Table 1. Xenotransplantation of organs, longest survival times, up to April 2016.

\begin{tabular}{|c|c|c|c|c|}
\hline $\begin{array}{l}\text { Recipient } \\
\text { (number of } \\
\text { animals) }\end{array}$ & Transgenes & Immunosuppressive regimen & $\begin{array}{l}\text { Longest } \\
\text { survival time } \\
\text { (median) days }\end{array}$ & Reference \\
\hline \multicolumn{5}{|c|}{ Heterotopic heart transplantation } \\
\hline Baboon (14) & CD55 & Cyp, CsA, CS, MMF & $99(26)$ & $\begin{array}{l}\text { Bhatti et al., } \\
1999[116]\end{array}$ \\
\hline Baboon (10) & CD46 & $\begin{array}{l}\text { ATG, splenectomy, anti-CD20mAb, tacrolimus, } \\
\text { rapamycin, CS, TPC }\end{array}$ & $113(76)$ & $\begin{array}{l}\text { McGregor et al. } \\
2004 \text { [117] }\end{array}$ \\
\hline Baboon (10) & CD55 & ATG, anti-CD20mAb, TI, CVF, anti-CD154mAb, MMF, CS & $139(27)$ & $\begin{array}{l}\text { Houser et al., } \\
2004[118]\end{array}$ \\
\hline Baboon (7) & CD46 & $\begin{array}{l}\text { ATG, splenectomy, anti-CD20mAb, tacrolimus, } \\
\text { rapamycin, CS, TPC }\end{array}$ & $137(96)$ & $\begin{array}{l}\text { McGregor et al., } \\
2005[119]\end{array}$ \\
\hline Baboon (13) & CD46 & $\begin{array}{l}\text { splenectomy, anti-CD } 20 \mathrm{mAb} \text {, tacrolimus, rapamycin, } \\
\text { TPC; heparin + ATG, CyP for rejection episodes }\end{array}$ & $109(18)$ & $\begin{array}{l}\text { Byrne et al., } \\
2005[120]\end{array}$ \\
\hline Baboon $(8+2)$ & $\begin{array}{l}\text { GTKO or low } \\
\text { expression }\end{array}$ & $\begin{array}{l}\text { ATG, TI, anti-CD2mAb, anti-CD154mAb, CVF, MMF, } \\
\text { methylprednisolone* }\end{array}$ & $179(78)$ & $\begin{array}{l}\text { Kuwaki et al., } \\
2005 \text { [44] } \\
\text { Tseng et al., } \\
2005 \text { [45] }\end{array}$ \\
\hline Baboon (63) & CD46 & $\begin{array}{l}\text { Splenectomy, anti-CD20mAb, tacrolimus, rapamycin, } \\
\text { TPC; aspirin/clopidogref or lovenox or warfarin }\end{array}$ & $139(96)$ & $\begin{array}{l}\text { Byrne et al., } \\
2006[46]\end{array}$ \\
\hline Baboon (7) & $\begin{array}{l}\text { GTKO, CD } 46 \\
\text { TBM or CD } 55\end{array}$ & Anti-CD20mAb, heparin ${ }^{\star \star}$ & 130 & $\begin{array}{l}\text { Iwase et al., } \\
2015[43]\end{array}$ \\
\hline Baboon (5) & $\begin{array}{l}\text { GTKO, CD46, } \\
\text { TBM }\end{array}$ & ATG, anti-CD20mAb, CVF, anti-CD40mAb, MMF, CS & $945(298)$ & $\begin{array}{l}\text { Mohiuddin et al., } \\
2013 \text { [392] } \\
\text { Mohiuddin et al., } \\
2016 \text { [41] }\end{array}$ \\
\hline \multicolumn{5}{|c|}{ Orthotopic heart transplantation } \\
\hline Baboon (10) & CD55 & CyP, CsA, CS & 9 & $\begin{array}{l}\text { Schmoeckel et al., } \\
1998[21]\end{array}$ \\
\hline Baboon (2) & WT & Immunosadsorption, $\mathrm{TBI}, \mathrm{CsA}$, methotrexate & 18,19 & $\begin{array}{l}\text { Xu et al., } \\
1998[122]\end{array}$ \\
\hline Baboon (1) & CD55 & CyP, CsA, MMF, CS & 39 & $\begin{array}{l}\text { Vial et al., } \\
2000[123]\end{array}$ \\
\hline Baboon (4) & CD55 & ATG, tacrolimus, rapamycin, CS, GAS914, CyP & 25 & $\begin{array}{l}\text { Brandl et al., } \\
2005 \text { [124] }\end{array}$ \\
\hline Baboon (4) & CD55 & CyP, CsA, CS, MMF & $20(14.6)$ & $\begin{array}{l}\text { Brenner et al., } \\
2005[125]\end{array}$ \\
\hline Baboon (13) & $\mathrm{CD} 55 / \mathrm{CD} 46$ & ATG, CyP, tacrolimus, rapamycin, CS, GAS914 & 25 & $\begin{array}{l}\text { Brandl et al., } \\
2007[126]\end{array}$ \\
\hline Baboon (14) & $\begin{array}{l}\text { CD46 or CD55 or } \\
\text { GTKO/CD } 55\end{array}$ & ATG,or CyP, tacrolimus, rapamycin, anti-CD20mAb & $57(6)$ & $\begin{array}{l}\text { Byrne et al., } \\
2011 \text { [127] }\end{array}$ \\
\hline \multicolumn{5}{|l|}{ Kidney } \\
\hline Cynomolgus (9) & CD55 & CyP, CsA, CS, splenectomy & $78(39)$ & $\begin{array}{l}\text { Cozzi et al., } \\
2000[128]\end{array}$ \\
\hline Cynomolgus (7) & CD55 & CyP, CsA, MMF, CS & $90(48)$ & $\begin{array}{l}\text { Baldan et al., } \\
2004 \text { [128] }\end{array}$ \\
\hline
\end{tabular}


Table 1 continued. Xenotransplantation of organs, longest survival times, up to April 2016.

\begin{tabular}{|c|c|c|c|c|}
\hline $\begin{array}{l}\text { Recipient } \\
\text { (number of } \\
\text { animals) }\end{array}$ & Transgenes & Immunosuppressive regimen & $\begin{array}{l}\text { Longest } \\
\text { survival time } \\
\text { (median) days }\end{array}$ & Reference \\
\hline Baboon (5) & GTKO & $\begin{array}{l}\text { Thymokidney, anti-CD2mAb, WBI, thymectomy, anti- } \\
\text { CD154mAb }\end{array}$ & $83(26)$ & $\begin{array}{l}\text { Yamada et al., } \\
2005[49]\end{array}$ \\
\hline Baboon (7) & GTKO & $\begin{array}{l}\text { Thymectomy, splenectomy, TBI, ATG, anti-CD2mAb, } \\
\text { anti-CD154mAb, tacrolimus, MMF }\end{array}$ & $83(49)$ & $\begin{array}{l}\text { Griesemer et al., } \\
2009[130]\end{array}$ \\
\hline Baboon (4) & GTKO & $\begin{array}{l}\text { ATG, anti-CD2mAb, anti-CD154mAb, MMF, CS, } \\
\text { thymectomy, spelectomy, thymokidney, }\end{array}$ & $83(52)$ & $\begin{array}{l}\text { Shimizu et al., } \\
2012[131]\end{array}$ \\
\hline Baboon (5) & CD55 & $\begin{array}{l}\text { thymokidney, thymectomy, splenectomy, } \\
\text { immunoadsorption, anti-CD2mAb, anti-CD 154mAb, } \\
\text { ATG, tacrolimus, CyP, CVF, MMF, CS }\end{array}$ & $229(27)$ & $\begin{array}{l}\text { Barth et al., } \\
2003 \text { [132] }\end{array}$ \\
\hline Rhesus (5) & GTKO/CD55 & Anti-CD4, anti-CD8, anti-CD154mAb, MMF, steroids & $>133(6->133)$ & $\begin{array}{l}\text { Higginbotham } \\
\text { et al., } 2015 \text { [41] }\end{array}$ \\
\hline Baboon (1) & $\begin{array}{l}\text { GTKO/CD46/ } \\
\text { CD55/TBM/ } \\
\text { EPCR/ } \\
\text { blood type } 0^{\#}\end{array}$ & $\begin{array}{l}\text { ATG, anti-CD20mAb, CVF, anti-CD40mAb, rapamycin, } \\
\text { MP\#\# }\end{array}$ & 163 & $\begin{array}{l}\text { Iwase et al., } \\
2015 \text { [42] }\end{array}$ \\
\hline
\end{tabular}

* Supportive therapy: prostacyclin, dopamine, ganciclovir, levofloxacin, cimetidine, heparin, antithrombin, aspirin; ${ }^{* *}$ two regimens were used, first ATG+anti-CD154mAb+CTLA4-Ig, second ATG+anti CD40mAb+CTLA4-Ig; " hTBM and hCD39 were not expressed in the kidney; \#\# in addition anti-inflammatory (tocilizumab, IL-6 receptor blockade, etanervept, TFN- $\alpha$ antagonist) and adjunctive (aspirin, low molecular weight heparin) treatment. ATG - anti-thymocyte globulin; CD46 - membrane cofactor protein; CD55 - decayaccelerating factor; CS - corticosteroids; CsA - cyclosporine; CTLA4-Ig - cytotoxic T-lymphocyte-associated protein 4 coupled to immunoglobulin; CVF - cobra venom factor; CyP - cyclophosphamide; EPCR - endothelial protein C receptor, CD39; GAS914 - a soluble glycoconjugate comprising Gal on a poly-L-lysine backbone; GTKO - $\alpha 1$,3-galactosyltransferase gene-knockout; MMF - mycophenolate mofetil (or analog, e.g. mycophenolate sodium]; MP - methylprednisolone; TBI - total body irradiation; TBM - thrombomodulin; $\mathrm{TI}$ - thymic irradiation; TPC - an $\alpha \mathrm{Gal}$-polyethylene glycol polymer conjugate.

including coagulation, have proved to be satisfactory, the immediate development of thrombocytopenia was extremely limiting. The thrombocytopenia resulted in hemorrhages in various organs and tissues, as well as in the transplanted liver [56].

Barriers to successful lung transplantation appear to be even greater than for other organs [58]. They may be related to anatomical factors such as the fragile lung parenchyma-associated blood supply, as well as the presence of large numbers of inflammatory cells. The longest survival of a pig lung after transplantation in a non-human primate has been 5 days [58]. In contrast to the longer survival times of heart and kidney transplantations, lung transplantations are comparable with liver transplantation, which reached the longest survival of 9 days [57].

\section{Microbiological Safety}

As already described in the introduction, PERVs are of special interest when analyzing the microbiological safety of xenotransplantation. Like endogenous retroviruses from other species, including humans, they are part of the genome and therefore cannot be eliminated, as in many other potentially zoonotic microorganisms in pigs, by SPF or DPF breeding [5]. PERV-A and PERV-B are in the genome of all pigs; PERV-C is common, but not present in all pigs. PERV-A and PERV-B are able to infect human cells, but PERV-C infects only pig cells. However, recombination between PERV-A and PERV-C resulted in recombinant $P E R V-A / C$ viruses, which are characterized by a very high replication rate. PERV-A/C were not found to be integrated in the germ line.

To date, there has been no reported transmission of PERVs in more than 200 individuals who had contact with pig tissues, either through islet cell transplantation or ex vivo perfusion of porcine livers and spleens. PERVs were also not transmitted in preclinical pig to non-human primate transplantations, or in infection experiments with small animals or non-human primates with or without pharmaceutical immunosuppression (for a review, see [5]). However, most of the individuals were not exposed for a long time to the xenotransplants and, with some exceptions (associated with parallel kidney allotransplantations), no immunosuppression had been applied. Non-human primates are not a suitable model in which to study the risk of PERV transmission because they (in contrast to humans) 
Table 2. Xenotransplantations of islet cells with the longest survival times, up to July 2015.

\begin{tabular}{|c|c|c|c|c|c|}
\hline $\begin{array}{l}\text { Number of } \\
\text { transplantation }\end{array}$ & $\begin{array}{l}\text { Recipient } \\
\text { (number of } \\
\text { animals) }\end{array}$ & $\begin{array}{l}\text { Transgenes (GE)/ } \\
\text { Encapsulation (E) }\end{array}$ & $\begin{array}{l}\text { Immunosuppressive } \\
\text { regimen }\end{array}$ & $\begin{array}{l}\text { Longest survival } \\
\text { time (days) }\end{array}$ & Reference \\
\hline 1 & Cynomolgus (2) & $\mathrm{E}$ & None & $>256$ & $\begin{array}{l}\text { Elliott et al., } \\
2005 \text { [133] }\end{array}$ \\
\hline 2 & Cynomolgus (4) & wt & $\begin{array}{l}\text { Anti-CD } 25 \mathrm{mAb}, \mathrm{FTY} 720 \text {, } \\
\text { rapamycin, anti-CD } 154 \mathrm{mAb} \text {, } \\
\text { tacrolimus, rapamycin, CS, TPC }\end{array}$ & 47 to 187 & $\begin{array}{l}\text { Hering et al., } \\
2006[18]\end{array}$ \\
\hline 3 & Rhesus (9) & wt & $\begin{array}{l}\text { Anti-CD } 25 \mathrm{mAb} \text {, } \\
\text { anti-CD } 154 \mathrm{mAb}, \text { CTLA4lg, } \\
\text { rapamycin }\end{array}$ & 4 to $>260(140)$ & $\begin{array}{l}\text { Cardona et al., } \\
2006[17]\end{array}$ \\
\hline 4 & Cynomolgus (9) & wt, GTKO, CD46 & ATG; anti-CD154mAb, MMF & 5 to 396 & $\begin{array}{l}\text { Van der Windt } \\
\text { et al., } 2009 \text { [134] }\end{array}$ \\
\hline 5 & Cynomolgus (2) & wt & $\begin{array}{l}\text { ATG; anti-CD25mAb, anti- } \\
\text { CD20mAb, FTY720, rapamycin, } \\
\text { CTLA4-Ig }\end{array}$ & 280,380 & $\begin{array}{l}\text { Hecht et al., } \\
2009 \text { [135] }\end{array}$ \\
\hline 6 & Rhesus (9) & wt & $\begin{array}{l}\text { Anti-CD25mAb, anti-CD40mAb, } \\
\text { rapamycin, CTLA4-Ig }\end{array}$ & 47 to $203(80)$ & $\begin{array}{l}\text { Thompson et al., } \\
2011[136]\end{array}$ \\
\hline 7 & Rhesus (10) & GTKO or wt & $\begin{array}{l}\text { Anti-CD 25mAb, anti-LAF1mAb, } \\
\text { MMF, CTLA4-lg }\end{array}$ & 50 to 249 (137) & $\begin{array}{l}\text { Thompson et al., } \\
2011[137]\end{array}$ \\
\hline 8 & Cynomolgus (6) & GTKO, CD46,CD39 & Anti-CD25mAb & 14 to 224 & $\begin{array}{l}\text { Veriter et al., } \\
2013[138]\end{array}$ \\
\hline 9 & Cynomolgus (5) & $3 G E-4 G E^{*}$ & Complex treatment ${ }^{\star *}$ & 0 to 365 (106) & $\begin{array}{l}\text { Bottino et al., } \\
2015[139]\end{array}$ \\
\hline 10 & Rhesus (5) & wt & $\begin{array}{l}\text { ATG, CVF, anti-CD 154mAb, } \\
\text { sirolimus }\end{array}$ & Up to 603 & $\begin{array}{l}\text { Shin et al., } \\
2015[140]\end{array}$ \\
\hline
\end{tabular}

* 3GE, GTKO,CD46, CD39; 4GE, GTKO,CD46, TFPI, CTL4-Ig; 5GE, GTKO,CD46, TFPI, CTL4-Ig, CD39; ** Prostacyclin, methylprednisolon, dextran sulfate, ATG, MMF, anti-CD154mAb. Abbreviations see Table 1.

carry a mutated receptor for PERV, only allowing infection with reduced efficacy (reviewed in [59]). Despite the presence of a functional receptor for PERV on human cells, no transmission of PERV was observed in the first clinical trials transplanting pig islet cells to treat diabetes in New Zealand [60] and Argentina [61]. Therefore, the question of whether PERVs may be transmitted during xenotransplantation is still open and an elimination of infectious proviruses is advised.

In contrast to PERVs, transmission of herpesviruses has been observed in experimental xenotransplantations, e.g., porcine cytomegalovirus (PCMV) from pig to cynomolgus monkeys [62] and baboons [63]. Transmission of a baboon cytomegalovirus (BCMV) after transplantation of baboon tissues to human recipients was also described [64]. Most of the potentially zoonotic microorganisms can be eliminated by Caesarean section and SPF or DPF breeding of the animals [65]. However, there are viruses that may be transmitted via the placenta and therefore may be present even in SPF/DPF facilities $[66,67]$. At present, it is still unclear which porcine microorganisms have a zoonotic potential when transmitted to human recipients.
The following viruses are considered potentially pathogenic: PERVs, PCMV, hepatitis E virus (HEV), porcine lymphotropic herpesviruses (PLHV-1, -2, and -3), porcine circoviruses (PCV1 and PCV2), and others (Table 3). PERVs were included on this list because retroviruses in general induce tumors and/or immunodeficiencies [68]. Examples are human immunodeficiency virus 1 (HIV-1), inducing AIDS, and the human T cell lymphotropic virus 1 (HTLV-1), inducing lymphoma and neurological diseases in humans. HEV is on this list because it has been shown to be transmitted from pigs to humans, either by close contact or by undercooked pork, causing hepatitis in numerous cases $[66,69,70]$. PCMV is on the list because it is related to human cytomegalovirus (HCMV). HCMV infections are in many cases fatal for immunosuppressed allotransplant recipients [71]. Although PCMV is more closely related to HHV6 and HHV-7 than to HCMV, designated now as HHV-5 [72], it has been shown that transmission of PCMV in pig to non-human primate kidney transplantation drastically reduced the survival time of the recipients $[62,63]$, suggesting that PCMV may have a similar effect in humans. PLHV-1, -2 , and -3 were found in large numbers on farm pigs (in $78 \%, 41 \%$, and $59 \%$ of the 
Table 3. Potentially zoonotic viruses in pigs.

\begin{tabular}{|c|c|c|}
\hline Viruses & Zoonotic potential & Diseases in pigs \\
\hline Porcine endogenous retrovirus (PERV) & Unknown & Unknown (tumour, immunodeficiency?) \\
\hline Porcine cytomegalovirus (PCMV) & Yes & Rhinitis*, immunosuppression? \\
\hline $\begin{array}{l}\text { Porcine reproductive and respiratory } \\
\text { syndrome virus (PRRSV) }\end{array}$ & No & $\begin{array}{l}\text { PRRS; respiratory diseases in young pigs and } \\
\text { reproductive diseases in sows }\end{array}$ \\
\hline Porcine circovirus type 2 (PCV2) & Unknown & PCVD; PMWS \\
\hline Hepatitis E virus (HEV) & Yes & Subclinical \\
\hline Menangle virus & Yes & Reproductive disease \\
\hline Porcine torovirus (PToV) & Unknown & Diarrhoea \\
\hline Porcine sapovirus (porcine SaV) & Potential & Diarrhoea \\
\hline Porcine lymphotropic herpesviruses (PLHV) & Unknown & Unknown but incriminated in PTLD \\
\hline Nipah virus (NiV) & Yes & $\begin{array}{l}\text { Respiratory and neurological } \\
\text { syndrome }\end{array}$ \\
\hline Torque teno sus virus (TTSuV) & Unknown & Unknown and PMWS \\
\hline Bungowannah virus & Unknown & Porcine myocarditis syndrome \\
\hline Porcine kobuvirus & Unknown & Unknown \\
\hline $\begin{array}{l}\text { Porcine bocavirus (PBoV) and other } \\
\text { related novel porcine parvoviruses }\end{array}$ & Unknown & Unknown \\
\hline
\end{tabular}

* Rhinitis in newborn piglets can be severe enough to cause haemorrhage from the nose. PRRS - porcine reproductive and respiratory syndrome; PCVD - porcine circovirus 2 diseases, previously; PMWS - post-weaning multisystemic wasting syndrome, PTLD - posttransplant lymphoproliferative disease.

lung tissue samples, and in $59 \%, 26 \%$ and $62 \%$ of the spleen samples, respectively [73]). Approximately $21 \%$ ( 9 of 44 ) of the miniature swine PBMC were also positive for PLHV DNA [74]. There is evidence that PLHV-1 is associated with post-transplant lymphoproliferative disease (PTLD) in miniature pigs following allogeneic hematopoietic stem-cell transplantation [75,76]. The clinical symptoms of experimental porcine PTLD, such as fever, lethargy, anorexia, high white blood cell count, and palpable lymph nodes, are similar to those of human PTLD, which was linked to the human herpesvirus Epstein-Barr virus, now designated HHV-4 [77]. Evidence of productive PLHV-1 infection was not detected in recipient baboons receiving different organs from transgenic pigs for up to 6 months of transplant function [78]. Appropriate breeding procedures can eliminate PLHV and piglets free of PLHV were produced via Caesarean section and barrier-reared breeding procedure [74]. In contrast to the porcine cytomegalovirus [PCMV], which can be excluded from source animals by early weaning of piglets, this was not possible in the case of PLHV [79]. With the exception of the PERVs, all potentially zoonotic viruses (Table 3 ) can be eliminated by SPF/DPF breeding. This includes Caesarean delivery and breeding in barrier facilities, and, if necessary, treatment of the pig herd with antiviral drugs $[66,80]$. Most important are the quality and sensitivity of the detection method; use of methods with low sensitivity could result in false-negative results.

Antiviral drugs have still not been used in pigs to treat infections. Ribavirin may be used for the treatment of HEV infections and ganciclovir, cidofovir, or other antiviral drugs for the treatment of PCMV infections, although PCMV - in contrast to the human CMV - is highly resistant to ganciclovir [81]. Combining treatment, selection, and (possibly) vaccination of the donor pigs, xenotransplantation can become a considerably safer technology compared with allotransplantation, in which transmissions of HIV-1, rabies virus, CMV, and other pathogens have been described [71].

To prevent transmission of PERVs, which are present in the genome of all pigs and cannot be eliminated by SPF/DPF breeding [5], several strategies have been developed. First, pigs can be selected that have a low copy number and a low expression at the RNA or protein level of PERV-A and PERV-B proviruses. Methods have been developed to discriminate between high and low expression of PERV in blood cells $[82,83]$. Second, PERV-C-free animals can be selected in order to avoid recombination between the ecotropic PERV-C (which infects only pig 
cells) and the human-tropic PERV-A. Such recombinant PERV$A / C$ are characterized by an increased replication competence compared with the parenteral virus [84-87]. Sensitive and specific methods have been developed to screen for PERV-Cpositive animals $[88,89]$. Third, RNA interference technology has been successfully used in transgenic pigs to reduce the expression of PERV in vitro [90-92] and in vivo [93-95]. Fourth, vaccination is an excellent tool to prevent virus transmission. Immunizing with the transmembrane and surface envelope (TM and SU, respectively) proteins of PERV in different species binding and neutralizing antibodies were obtained, suggesting that this may also be possible in humans [96-98]. Fifth, since PERV is present in up to approximately 100 copies in the genome, it is a challenge to knock out all proviruses in the genome using gene editing. When gene editing was performed using the zinc finger nuclease (ZFN), the expression of ZFN was very high, inducing a toxic effect when the nucleases were cutting in multiple sites and destabilizing the genome [99]. When the Clustered Regularly Interspaced Short Palindromic Repeats/CRISPR-associated (CRISPR/Cas9) technology [100-102] was used, a breakthrough was achieved. Sixtytwo PERV proviruses were knocked-out in immortalized PK-15 pig cells [103]. If it will be possible to knock out all infectious PERV proviruses in primary cells and to obtain piglets not releasing PERV, these retroviruses are no longer a risk for xenotransplantation [104]. To summarize, efficient strategies have been developed to identify and to prevent transmission of porcine microorganisms with zoonotic potential, including PERVs.

\section{Ethical Aspects and Regulation}

Although not a topic of this review, it should be mentioned that theological-ethical [105-107] and regulatory aspects of xenotransplantation are being broadly discussed. The International Xenotransplantation Association [IXA] recently published the first update of a consensus paper dealing with different aspects of efficient and safe islet cell xenotransplantation [108-115]. One contribution to this consensus paper provides a detailed description of national regulatory frameworks [109].

\section{Conclusions}

Here, we demonstrated numerous steps forward to bring xenotransplantation towards clinical application. First of all, multitransgenic pigs were created in order to prevent rejection of the pig cells and organs. Second, new immunosuppression regimens were introduced, also in order to prevent rejection. Third, based on these achievements, longer survival times of transplanted pig hearts, kidneys, liver, and islet cells have been observed in preclinical trials. Fourth, new and sensitive methods have been developed to screen the donor pigs for potential zoonotic microorganisms, making xenotransplantation eventually safer compared with allotransplantation, where in rare cases HIV-1, rabies virus, HCMV, and other pathogens have been transmitted [71]. Fifth, the discussion on ethical aspects is ongoing, an updated consensus document on how to perform safe and efficient xenotransplantation was prepared by the scientific community, and in several countries a national regulatory framework was prepared. All these achievements will allow clinical application of xenotransplantation in the near future.

Two major fields in xenotransplantation research are in need of improvement. First, although pigs with multiple genetic modifications have been produced with great effort and expense, in most cases their advantage compared to other genetically modified pigs was not fully evaluated. Second, microbiological characterization of the donor pigs has, in the past, not been sufficiently thorough, and as a result, pig to non-human primate transplantations have been performed that resulted in the transmission of pathogenic microorganisms and the premature death of the recipients. For example, the transmission of PCMV to cynomolgus monkeys and baboons, significantly reducing survival time, has been reported $[62,63]$. Additional financial support and scientific investigations have to be devoted to studies of viral safety, the results of which should automatically contribute to increasing the survival times of xenotransplants and their recipients.

\section{References:}

1. Galili U: The alpha-gal epitope and the anti-Gal antibody in xenotransplantation and in cancer immunotherapy. Immunol Cell Biol, 2005; 83: 674-86

2. Kobayashi T, Cooper DK: Anti-Gal, alpha-Gal epitopes, and xenotransplantation. Subcell Biochem, 1999; 32: 229-57

3. Phelps CJ, Koike C, Vaught TD et al: Production of alpha 1,3-galactosyltransferase-deficient pigs. Science, 2003; 299(5605): 411-14

4. Petersen B, Carnwath JW, Niemann H: The perspectives for porcine-to-human xenografts. Comp Immunol Microbiol Infect Dis, 2009; 32(2): 91-105

5. Denner J, Tonjes RR: Infection barriers to successful xenotransplantation focusing on porcine endogenous retroviruses. Clin Microbiol Rev, 2012; 25: 318-43

6. Wilhite $\mathrm{T}$, Ezzelarab C, Hara $\mathrm{H}$ et al: The effect of Gal expression on pig cells on the human T-cell xenoresponse. Xenotransplantation, 2012; 19(1): 56-63

7. Phelps CJ, Ball SF, Vaught TD et al: Production and characterization of transgenic pigs expressing porcine CTLA4-Ig. Xenotransplantation, 2009; 16(6): 477-85

8. Iwase H, Ekser B, Satyananda V et al: Pig-to-baboon heterotopic heart transplantation - exploratory preliminary experience with pigs transgenic for human thrombomodulin and comparison of three costimulation blockade-based regimens. Xenotransplantation, 2015; 22(3): 211-20 
9. Hara H, Witt W, Crossley T et al: Human dominant-negative class II transactivator transgenic pigs - effect on the human anti-pig T-cell immune response and immune status. Immunology, 2013; 140(1): 39-46

10. Bouhours D, Pourcel C, Bouhours JE: Simultaneous expression by porcine aorta endothelial cells of glycosphingolipids bearing the major epitope for human xenoreactive antibodies (Gal alpha 1-3Gal), blood group $\mathrm{H}$ determinant and N-glycolylneuraminic acid. Glycoconj J, 1996; 13(6): 947-53

11. Lutz AJ, Li P, Estrada JL et al: Double knockout pigs deficient in $\mathrm{N}$-glycolylneuraminic acid and galactose $\alpha$-1,3-galactose reduce the humoral barrier to xenotransplantation. Xenotransplantation, 2013; 20(1) 27-35

12. Burlak C, Paris LL, Lutz AJ et al: Reduced binding of human antibodies to cells from GGTA1/CMAH KO pigs. Am J Transplant, 2014; 14(8): 1895-900

13. Burdorf $L$, Stoddard T, Zhang T et al: Expression of human CD46 modulates inflammation associated with GalTKO lung xenograft injury. Am J Transplant, 2014; 14(5): 1084-95

14. Petersen B, Ramackers W, Lucas-Hahn A et al: Transgenic expression of human heme oxygenase- 1 in pigs confers resistance against xenograft rejection during ex vivo perfusion of porcine kidneys. Xenotransplantation, 2011; 18: 355-68

15. Oropeza M, Petersen B, Carnwath JW et al: Transgenic expression of the human $\mathrm{A} 20$ gene in cloned pigs provides protection against apoptotic and inflammatory stimuli. Xenotransplantation, 2009; 16: 522-34

16. Petersen B, Ramackers W, Tiede A et al: Pigs transgenic for human thrombomodulin have elevated production of activated protein $C$. Xenotransplantation, 2009; 16: 486-95

17. Cardona K, Korbutt GS, Milas Z et al: Long-term survival of neonatal porcine islets in nonhuman primates by targeting costimulation pathways. Nat Med, 2006; 12: 304-6

18. Hering BJ, Wijkstrom M, Graham ML et al: Prolonged diabetes reversal after intraportal xenotransplantation of wild-type porcine islets in immunosuppressed nonhuman primates. Nat Med, 2006; 12: 301-3

19. Mohiuddin MM, Singh AK, Corcoran PC et al: Genetically engineered pigs and target-specific immunomodulation provide significant graft survival and hope for clinical cardiac xenotransplantation. J Thorac Cardiovasc Surg, 2014; 148: 1106-13

20. Ezzelarab M, Garcia B, Azimzadeh A et al: The innate immune response and activation of coagulation in alpha1,3-galactosyltransferase gene-knockout xenograft recipients. Transplantation, 2009; 87: 805-12

21. Poirier N, Azimzadeh AM, Zhang T et al: Inducing CTLA-4-dependent immune regulation by selective CD28 blockade promotes regulatory $T$ cells in organ transplantation. Sci Translat Med, 2010; 2: 17ra10

22. Klymiuk N, van Buerck L, Bähr A et al: Xenografted islet cell clusters from INSLEA29Y transgenic pigs rescue diabetes and prevent immune rejection in humanized mice. Diabetes, 2012; 61: 1527-32

23. Del Rio ML, Seebach JD, Fernandez-Renedo C, Rodriguez-Barbosa J: ITIMdependent negative signaling pathways for the control of cell-mediated xenogeneic immune responses. Xenotransplantation, 2013; 20: 397-406

24. Ding Q, Lu L, Zhou X et al: Human PD-L1-overexpressing porcine vascular endothelial cells induce functionally suppressive human CD4+CD25hiFoxp3+ Treg cells. J Leukoc Biol, 2011; 90: 77-86

25. Plege-Fleck A, Lieke T, Römermann D et al: Pig to rat cell transplantation: reduced cellular and antibody responses to xenografts overexpressing PDL1. Xenotransplantation, 2014; 21(6): 533-42

26. Reichart B, Niemann $\mathrm{H}$, Chavakis $\mathrm{T}$ et al: Xenotransplantation of porcine islet cells as a potential option for the treatment of type 1 diabetes in the future. Horm Metab Res, 2015; 47(1): 31-35

27. Waldmann H, Adams E, Fairchild $P$, Cobbold S: Regulation and privilege in transplantation tolerance. J Clin Immunol, 2008; 28: 716-25

28. Muller YD, Golshayan D, Ehirchiou D et al: $T$ regulatory cells in xenotransplantation. Xenotransplantation, 2009; 16: 121-28

29. Inverardi L, Pardi R: Early events in cell-mediated recognition of vascularized xenografts: cooperative interactions between selected lymphocyte subsets and natural antibodies. Immunol Rev, 1994; 141: 71-93

30. Schneider MK, Seebach JD: Current cellular innate immune hurdles in pigto-primate xenotransplantation. Curr Opin Organ Transplant, 2008; 13 171-77

31. Li S, Waer M, Billiau AD: Xenotransplantation: role of natural immunity. Transplant Immunol, 2009; 21: 70-74
32. Weiss EH, Lilienfeld BG, Muller S et al: HLA-E/human beta2-microglobulin transgenic pigs: Protection against xenogeneic human anti-pig natural killer cell cytotoxicity. Transplantation, 2009; 87: 35-43

33. Marigliano $M$, Bertera $S$, Grupillo $M$ et al: Pig-to-nonhuman primates pancreatic islet xenotransplantation: an overview. Curr Diab Rep, 2011; 11 402-12

34. Goto M, Tjernberg J, Dufrane D et al: Dissecting the instant blood-mediated inflammatory reaction in islet xenotransplantation. Xenotransplantation, 2008; 15: 225-34

35. Cooper DK, Satyananda V, Ekser B et al: Progress in pig-to-non-human primate transplantation models (1998-2013): A comprehensive review of the literature. Xenotransplantation, 2014; 21(5): 397-419

36. McGregor CG, Ricci D, Miyagi $N$ et al: Human CD55 expression blocks hyperacute rejection and restricts complement activation in Gal knockout cardiac xenografts. Transplantation, 2012; 93(7): 686-92

37. Mohiuddin MM, Corcoran PC, Singh AK et al: B-cell depletion extends the survival of GTKO.hCD46Tg pig heart xenografts in baboons for up to 8 months. Am J Transplant, 2012; 12(3): 763-71

38. Mohiuddin MM, Singh AK, Corcoran PC et al: Genetically engineered pigs and target-specific immunomodulation provide significant graft survival and hope for clinical cardiac xenotransplantation. J Thorac Cardiovasc Surg, 2014; 148(3): 1106-13

39. Mohiuddin MM, Singh AK, Corcoran PC et al: One-year heterotopic cardiac xenograft survival in a pig to baboon model. Am J Transplant, 2014; 14(2): 488-89

40. Mohiuddin MM, Singh AK, Corcoran PC et al: Role of anti-CD40 antibodymediated costimulation blockade on non-Gal antibody production and heterotopic cardia c xenograft survival in a GTKO.hCD46Tg pig-to-baboon model. Xenotransplantation, 2014; 21(1): 35-45

41. Mohiuddin MM, Singh AK, Corcoran PC et al: Chimeric 2C10R4 anti-CD40 antibody therapy is critical for long-term survival of GTKO.hCD46.hTBM pigto-primate cardiac xenograft. Nat Commun, 2016; 7: 11138

42. Higginbotham L, Mathews D, Breeden CA et al: Pre-transplant antibody screening and anti-CD154 costimulation blockade promote long term xenograft survival in a pig-to-primate kidney transplant model. Xenotransplantation, 2015; 22(3): 221-30

43. Iwase $\mathrm{H}$, Liu $\mathrm{H}$, Wijkstrom $\mathrm{M}$ et al: Pig kidney graft survival in a baboon for 136 days: Longest life-supporting organ graft survival to date. Xenotransplantation. 2015; 22(4): 302-9

44. Kuwaki K, Tseng YL, Dor FJ et al: Heart transplantation in baboons using alpha1,3-galactosyltransferase gene-knockout pigs as donors: Initial experience. Nat Med, 2005; 11(1): 29-31

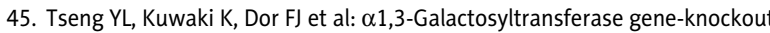
pig heart transplantation in baboons with survival approaching 6 months. Transplantation, 2005; 80: 1493-500

46. Byrne GW, Davies WR, Oi K et al: Increased immunosuppression, not anticoagulation, extends cardiac xenograft survival. Transplantation. 2006; 82(12): 1787-91

47. Michler RE: Xenotransplantation: Risks, clinical potential, and future pros pects. Emerg Infect Dis, 1996; 2(1): 64-70

48. Cozzi $E$, Bhatti $F$, Schmoeckel $M$ et al: Long-term survival of non-human primates receiving life-supporting transgenic porcine kidney xenografts. Transplantation, 2000; 70(1): 15-21

49. Yamada K, Yazawa K, Shimizu A et al: Marked prolongation of porcine renal xenograft survival in baboons through the use of alpha1,3-galactosyltransferase gene-knockout donors and the cotransplantation of vascularized thymic tissue. Nat Med, 2005; 11(1): 32-34

50. Azimzadeh A, Kelishadi S, Ezzelarab MB et al: Early graft failure of GalTKO pig organs in baboons is reduced by expression of a human complementregulatory protein. Xenotransplantation, 2015; 22(4): 310-16

51. Ekser B, Gridelli B, Veroux $M$ et al: Clinical pig liver xenotransplantation How far do we have to go? Xenotransplantation, 2011; 18(3): 158-67

52. Hara H, Gridelli B, Lin YJ et al: Liver xenografts for the treatment of acute liver failure: Clinical and experimental experience and remaining immunologic barriers. Liver Transplant, 2008; 14: 425-34

53. Ekser B, Gridelli B, Tector AJ, Cooper DK: Pig liver xenotransplantation as a bridge to allotransplantation: Which patients might benefit? Transplantation, 2009; 88(9): 1041-49

54. Soin B, Smith KG, Zaidi A et al: Physiological aspects of pig-to-primate renal xenotransplantation. Kidney Int, 2001; 60(4): 1592-97 
55. Ekser B, Burlak C, Waldman JP et al: Immunobiology of liver xenotransplantation. Expert Rev Clin Immunol, 2012; 8(7): 621-34

56. Ekser B, Long C, Echeverri GJ et al: Impact of thrombocytopenia on survival of baboons with genetically modified pig liver transplants: Clinical relevance. Am J Transplant, 2010; 10(2): 273-85

57. Yeh H, Machaidze Z, Wamala I et al: Increased transfusion-free survival following auxiliary pig liver xenotransplantation. Xenotransplantation. 2014; 21(5): 454-64

58. Cantu E, Balsara KR, Li B et al: Prolonged function of macrophage, von Willebrand factor-deficient porcine pulmonary xenografts. Am J Transplant, 2007; 7(1): 66-75

59. Denner J, Graham M: Xenotransplantation of islet cells: what can the nonhuman primate model bring for the evaluation of efficacy and safety? Xenotransplantation, 2015; 22(3): 231-35

60. Wynyard S, Nathu D, Garkavenko $O$ et al: Microbiological safety of the first clinical pig islet xenotransplantation trial in New Zealand. Xenotransplantation, 2014; 21(4): 309-23

61. Morozov VA, Wynyard S, Matsumoto $S$ et al: No PERV transmission during a clinical trial of pig islet cell transplantation. Virus Res [in press]

62. Sekijima M, Waki S, Sahara $\mathrm{H}$ et al: Results of life-supporting galactosyltransferase knockout kidneys in cynomolgus monkeys using two different sources of galactosyltransferase knockout Swine. Transplantation, 2014; 98(4): 419-26

63. Yamada K, Tasaki M, Sekijima $M$ et al: Porcine cytomegalovirus infection is associated with early rejection of kidney grafts in a pig to baboon xenotransplantation model. Transplantation, 2014; 98(4): 411-18

64. Michaels MG, Jenkins FJ, St. George K et al: Detection of Infectious Baboon Cytomegalovirus after Baboon-to-Human Liver Xenotransplantation. J Virol., 2001; 75(6): 2825-28

65. Fishman JA: Assessment of infectious risk in clinical xenotransplantation: The lessons for clinical allotransplantation. Xenotransplantation, 2014 21(4): 307-8

66. Denner J: Xenotransplantation and Hepatitis E virus. Xenotransplantation, 2015; 22(3): 167-73

67. Mueller NJ, Fishman JA: Herpesvirus infections in xenotransplantation: Pathogenesis and approaches. Xenotransplantation, 2004; 11: 486-90.

68. Coffin JM, Hughes SH, Varmus HE: Retroviruses. Cold Spring Harbor, New York: Cold Spring Harbor Laboratory Press; 1997

69. Meng XJ: Zoonotic and foodborne transmission of hepatitis E virus. Semin Liver Dis, 2013; 33(1): 41-49

70. Johne R, Dremsek P, Reetz J et al: Hepeviridae: an expanding family of vertebrate viruses. Infect Genet Evol, 2014; 27: 212-29

71. Fishman JA, Grossi PA: Donor-derived infection - the challenge for transplant safety. Nat Rev Nephrol, 2014; 10(11): 663-72

72. Gu W, Zeng N, Zhou L et al: Genomic organization and molecular characterization of porcine cytomegalovirus. Virology, 2014; 460-461: 165-72

73. Chmielewicz B, Goltz M, Franz T et al: A novel porcine gammaherpesvirus. Virology, 2003; 308: 317-29

74. Tucker AW, McNeilly F, Meehan B et al: Methods for the exclusion of circoviruses and gammaherpesviruses from pigs. Xenotransplantation, 2003; 10: $343-48$

75. Huang CA, Fuchimoto Y, Gleit ZL et al: Posttransplantation lymphoproliferative disease in miniature swine after allogeneic hematopoietic cell transplantation: Similarity to human PTLD and association with a porcine gammaherpesvirus. Blood, 2001; 97: 1467-73

76. Goltz M, Ericsson T, Patience $C$ et al: Sequence analysis of the genome of porcine lymphotropic herpesvirus 1 and gene expression during posttransplant lymphoproliferative disease of pigs. Virology, 2002; 294: 383-93

77. Zimmermann H, Trappe RU: EBV and posttransplantation lymphoproliferative disease: what to do? Hematology Am Soc Hematol Educ Program, 2013; 2013: 95-102

78. Issa NC, Wilkinson RA, Griesemer A et al: Absence of replication of porcine endogenous retrovirus and porcine lymphotropic herpesvirus type 1 with prolonged pig cell microchimerism after pig-to-baboon xenotransplantation. J Virol, 2008; 82: 12441-48

79. Mueller NJ, Kuwaki K, Knosalla C et al: Early weaning of piglets fails to exclude porcine lymphotropic herpesvirus. Xenotransplantation, 2005; 12: 59-62

80. Denner J: Xenotransplantation and porcine cytomegalovirus (PCMV) Xenotransplantation, 2015; 22(5): 329-35
81. Mueller NJ, Sulling K, Gollackner B et al: Reduced efficacy of ganciclovir against porcine and baboon cytomegalovirus in pig-to-baboon xenotransplantation. Am J Transplant, 2003; 3(9): 1057-64

82. Tacke SJ, Specke V, Denner J: Differences in release and determination of subtype of porcine endogenous retroviruses produced by stimulated normal pig blood cells. Intervirology, 2003; 46(1): 17-24

83. Semaan M, Rotem A, Barkai U et al: Screening pigs for xenotransplantation: prevalence and expression of porcine endogenous retroviruses in Göttingen minipigs. Xenotransplantation, 2013; 20(3): 148-55

84. Wilson CA, Wong S, VanBrocklin M, Federspiel MJ: Extended analysis of the in vitro tropism of porcine endogenous retrovirus. J Virol, 2000; 74(1) 49-56

85. Wilson CA: Will some pig breeds or tissues be less likely to express infectious PERV? Transplantation, 2001; 72(12): 1865-66

86. Denner J, Specke V, Thiesen U et al: Genetic alterations of the long terminal repeat of an ecotropic porcine endogenous retrovirus during passage in human cells. Virology, 2003; 314(1): 125-33

87. Harrison I, Takeuchi Y, Bartosch B, Stoye JP: Determinants of high titer in recombinant porcine endogenous retroviruses. J Virol 2004; 78(24): 13871-79

88. Kaulitz D, Mihica D, Adlhoch C et al: Improved pig donor screening including newly identified variants of porcine endogenous retrovirus-C (PERV-C). Arch Virol, 2013; 158(2): 341-48

89. Kaulitz D, Mihica D, Dorna J et al: Development of sensitive methods for detection of porcine endogenous retrovirus-C (PERV-C) in the genome of pigs. J Virol Methods, 2011; 175(1): 60-5

90. Karlas A, Kurth R, Denner J: Inhibition of porcine endogenous retroviruses by RNA interference: Increasing the safety of xenotransplantation. Virology, 2004; 325(1): 18-23

91. Dieckhoff B, Karlas A, Hofmann A et al: Inhibition of porcine endogenous retroviruses (PERVs) in primary porcine cells by RNA interference using lentiviral vectors. Arch Virol, 2007; 152(3): 629-34

92. Miyagawa S, Nakatsu S, Nakagawa T et al: Prevention of PERV infections in pig to human xenotransplantation by the RNA interference silences gene. J Biochem, 2005; 137: 503-8

93. Dieckhoff B, Petersen B, Kues WA et al: Knockdown of porcine endogenous retrovirus (PERV) expression by PERV-specific shRNA in transgenic pigs. Xenotransplantation, 2008; 15(1): 36-45

94. Ramsoondar J, Vaught T, Ball S et al: Production of transgenic pigs that express porcine endogenous retrovirus small interfering RNAs. Xenotransplantation, 2009; 16(3): 164-80

95. Semaan M, Kaulitz D, Petersen B et al: Long-term effects of PERV-specific RNA interference in transgenic pigs. Xenotransplantation, 2012; 19(2): 112-21

96. Kaulitz D, Fiebig $U$, Eschricht $M$ et al: Generation of neutralising antibodies against porcine endogenous retroviruses (PERVs). Virology, 2011; 411(1): 78-86

97. Waechter A, Eschricht M, Denner J: Neutralization of porcine endogenous retrovirus by antibodies against the membrane-proximal external region of the transmembrane envelope protein. J Gen Virol, 2013; 94(3): 643-51

98. Denner J, Mihica D, Kaulitz D, Schmidt CM: Increased titers of neutralizing antibodies after immunization with both envelope proteins of the porcine endogenous retroviruses (PERVs). Virol J, 2012; 9: 260

99. Semaan M, Ivanusic D, Denner J: Cytotoxic effects during knock out of multiple porcine endogenous retrovirus (PERV) sequences in the pig genome by zinc finger nucleases (ZFN). PLoS One, 2015; 10(4): e0122059

100. Hsu PD, Lander ES, Zhang F: Development and applications of CRISPR-Cas 9 for genome engineering. Cell, 2014; 157(6): 1262-78

101. Doudna JA, Charpentier E: Genome editing. The new frontier of genome engineering with CRISPR-Cas9. Science, 2014; 346(6213): 1258096

102. Feng W, Dai $Y$, Mou $L$ et al: The potential of the combination of CRISPR/ Cas9 and pluripotent stem cells to provide human organs from chimaeric pigs. Int J Mol Sci, 2015; 16(3): 6545-56

103. Yang L, Güell M, Niu D et al: Genome-wide inactivation of porcine endog enous retroviruses (PERVs). Science, 2015; 350(6264): 1101-4

104. Denner, J: Elimination of porcine endogenous retroviruses from pig cells. Xenotransplantation. 2015; 22: 411-12

105. Green RM: Commentary. Xenotransplantation, 2015; 22: 192-93

106. Sautermeister J, Mathieu R, Bogner V: Xenotransplantation-theological-ethical considerations in an interdisciplinary symposium. Xenotransplantation, 2015; 22(3): 174-82 
107. Sautermeister J: Xenotransplantation from the perspective of moral theology. Xenotransplantation. 2015; 22(3): 183-91

108. Hering BJ, Cozzi E, Spizzo T et al: First update of the International Xenotransplantation Association consensus statement on conditions for under taking clinical trials of porcine islet products in type 1 diabetes Executive summary. Xenotransplantation, 2016; 23: 3-13

109. Cozzi E, Tönjes RR, Gianello $P$ et al: First update of the International Xenotransplantation Association consensus statement on conditions for undertaking clinical trials of porcine islet products in type 1 diabetes Chapter 1: Update on national regulatory frameworks pertinent to clinical islet xenotransplantation. Xenotransplantation, 2016; 23(1): 14-24

110. Spizzo T, Denner J, Gazda L et al: First update of the International Xenotransplantation Association consensus statement on conditions for undertaking clinical trials of porcine islet products in type 1 diabetes-Chapter 2a: Source pigs-preventing xenozoonoses. Xenotransplantation, 2016; 23(1): 25-31

111. Cowan PJ, Ayares D, Wolf E, Cooper DKC: First update of the International Xenotransplantation Association consensus statement on conditions for undertaking clinical trials of porcine islet products in type 1 diabetes Chapter 2b: Genetically modified source pigs. Xenotransplantation, 2016; 23: 32-37

112. Rayat GR, Gazda LS, Hawthorne WJ et al: First update of the International Xenotransplantation Association consensus statement on conditions for undertaking clinical trials of porcine islet products in type 1 diabetes Chapter 3: Porcine islet product manufacturing and release testing criteria. Xenotransplantation, 2016; 23(1): 38-45

113. Cooper DK, Bottino R, Gianello P et al: First update of the International Xenotransplantation Association consensus statement on conditions for undertaking clinical trials of porcine islet products in type 1 diabetes Chapter 4: Pre-clinical efficacy and complication data required to justify a clinical trial. Xenotransplantation, 2016; 23(1): 46-52

114. Denner J, Tönjes RR, Takeuchi $Y$ et al: First update of the International Xenotransplantation Association consensus statement on conditions for undertaking clinical trials of porcine islet products in type 1 diabetes Chapter 5: Recipient monitoring and response plan for preventing disease transmission. Xenotransplantation, 2016; 23(1): 53-59

115. Hering BJ, O'Connell PJ: First update of the International Xenotransplantation Association consensus statement on conditions for undertaking clinical trials of porcine islet products in type 1 diabetes - Chapter 6: Patient selection for pilot clinical trials of islet xenotransplantation. Xenotransplantation, 2016; 23: 60-76

116. Bhatti FN, Schmoeckel M, Zaidi A et al: Three-month survival of HDAFF transgenic pig hearts transplanted into primates. Transplant Proc, 1999; 31(1-2): 958

117. McGregor CG, Teotia SS, Byrne GW et al: Cardiac xenotransplantation: Progress toward the clinic. Transplantation, 2004; 78(11): 1569-75

118. Houser SL, Kuwaki K, Knosalla C et al: Thrombotic microangiopathy and graft arteriopathy in pig hearts following transplantation into baboons. Xenotransplantation, 2004; 11(5): 416-25

119. McGregor CG, Davies WR, Oi K et al: Cardiac xenotransplantation: Recent preclinical progress with 3-month median survival. J Thorac Cardiovasc Surg, 2005; 130(3): 844-51

120. Byrne GW, Schirmer JM, Fass DN et al: Warfarin or low-molecular-weight heparin therapy does not prolong pig-to-primate cardiac xenograft function. Am J Transplant, 2005; 5(5): 1011-20

121. Schmockel M, Bhatti FN, Zaidi A et al: Orthotopic heart transplantation in a transgenic pig-to-primate model. Transplantation, 1998; 65: 1570-77
122. Xu H, Gundry SR, Hancock WW et al: Prolonged discordant xenograft survival and delayed xenograft rejection in a pig to baboon heart xenograft model. Thorac Cardiovasc Surg, 1998; 115: 1342-49

123. Vial CM, Ostlie DJ, Bhatti FN et al: Life supporting function over one month of a transgenic porcine heart in a baboon. J Heart Lung Transplant, 2000; 19: 224-29

124. Brandl U, Michel S, Erhardt $M$ et al: Administration of GAS914 in an orthotopic pig-to-baboon heart transplantation model. Xenotransplantation, 2005; 12: 134-41

125. Brenner $P$, Schmoeckel M, Wimmer $C$ et al: Mean xenograft survival of 14.6 days in a small group of hDAF-transgenic pig hearts transplanted orthotopically into baboons. Transplant Proc, 2005; 37(1): 472-76

126. Brandl U, Michel S, Erhardt $M$ et al: Transgenic animals in experimental Xenotransplantation models: Orthotopic heart transplantation in the pig to baboon model. Transplant Proc, 2007; 39: 577-78

127. Byrne GW, Du Z, Sun Z et al: Changes in cardiac gene expression after pig to- primate orthotopic xenotransplantation. Xenotransplantation, 2011; 8: $14-27$

128. Cozzi E, Bhatti F, Schmoeckel $M$ et al: Long-term survival of non-human primates receiving life-supporting transgenic porcine kidney xenografts. Transplantation, 2000; 70: 15-21

129. Baldan N, Rigotti P, Calabrese F et al: Ureteral stenosis in HDAF pig-to-primate renal xenotransplantation: A phenomenon related to immunological events? Am J Transplant, 2004; 4(4): 475-81

130. Griesemer AD, Hirakata A, Shimizu A et al: Results of gal-knockout porcine thymokidney xenografts. Am J Transplant, 2009; 9(12): 2669-78

131. Shimizu A, Hisashi Y, Kuwaki K et al: Thrombotic microangiopathy associated with humoral rejection of cardiac xenografts from alpha1,3-galactosyltransferase gene-knockout pigs in baboons. Am J Pathol, 2008; 172(6) 1471-81

132. Barth RN, Yamamoto S, LaMattina JC et al: Xenogeneic thymokidney and thymic tissue transplantation in a pig-to-baboon model: I. Evidence for pigspecific T-cell unresponsiveness. Transplantation, 2003; 75(10): 1615-24

133. Elliott RB, Escobar L, Tan PL: Intraperitoneal alginate-encapsulated neonatal porcine islets in a placebo-controlled study with 16 diabetic cynomolgus primates. Transplant Proc, 2005; 37(8): 3505-8

134. van der Windt DJ, Bottino R, Casu A et al: Long-term controlled normogly cemia in diabetic non-human primates after transplantation with hCD46 transgenic porcine islets. Am J Transplant, 2009; 9(12): 2716-26

135. Hecht G, Eventov-Friedman S, Rosen C et al: Embryonic pig pancreatic tissue for the treatment of diabetes in a nonhuman primate model. Proc Nat Acad Sci USA, 2009; 106(21): 8659-64

136. Thompson $\mathrm{P}$, Cardona $\mathrm{K}$, Russell $\mathrm{M}$ et al: $\mathrm{CD} 40$-specific costimulation block ade enhances neonatal porcine islet survival in nonhuman primates. Am J Transplant, 2011; 11(5): 947-57

137. Thompson $P$, Badell IR, Lowe $M$ et al: Islet xenotransplantation using gal-deficient neonatal donors improves engraftment and function. Am J Transplant, 2011; 11(12): 2593-602

138. Vériter S, Aouassar N, Beaurin G et al: Improvement of pig islet function by in vivo pancreatic tissue remodeling: A "human-like" pig islet structure with streptozotocin treatment. Cell Transplant, 2013; 22(11): 2161-73

139. Bottino R, Wijkstrom M, van der Windt DJ et al: Pig-to-monkey islet xenotransplantation using multi-transgenic pigs. Am J Transplant, 2014; 14(10): 2275-87

140. Shin JS, Kim JM, Kim JS et al: Long-term control of diabetes in immunosuppressed nonhuman primates (NHP) by the transplantation of adult porcine islets. Am J Transplant, 2015; 15(11): 2837-50 